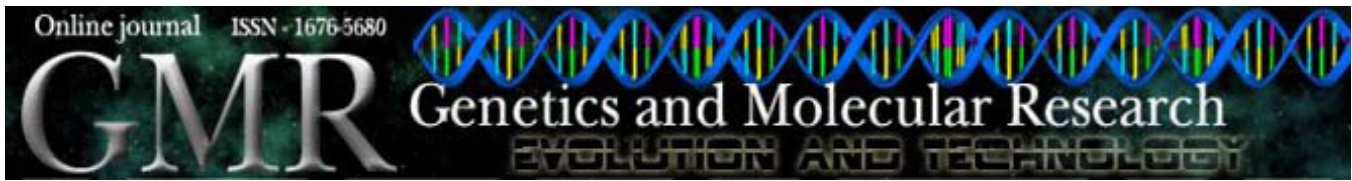

Letter to the Editor

\title{
Comments to the paper by Ambrósio CE, Fadel L, Gaiad TP, Martins DS, et al. [Identification of three distinguishable phenotypes in golden retriever muscular dystrophy (Genet. Mol. Res. 2009 Apr 7;8 (2): 389-396)]
}

\author{
E. Zucconi, T. Jazedje, M.C. Valadares and M. Zatz \\ Centro de Estudos do Genoma Humano, \\ Instituto de Biociências, \\ Universidade de São Paulo, São Paulo, SP, Brasil \\ Corresponding author: M. Zatz \\ E-mail: mayazatz@usp.br
}

Genet. Mol. Res. 8 (3): 818-821 (2009)

Received June 12, 2009

Published July 21, 2009

Dear Sir,

The group of geneticists (E. Zucconi, T. Jazedje, M.C. Valadares and M. Zatz) from the Department of Genetic and Evolutive Biology of the University of São Paulo, would like to correct important mistakes in the article entitled "Identification of three distinguishable phenotypes in golden retriever muscular dystrophy" published in the GMR Journal by C.E. Ambrósio et al., in April 2009. This article was written and sent for publication without our knowledge. Our group has been a reference in the study of progressive muscular dystrophies for many years and when we had access to this publication, we detected many wrong information regarding Duchenne muscular dystrophy (DMD) and golden retriever muscular dystrophy (GRMD). We would like also to point out that our contribution in this paper was restricted to the molecular analysis of GRMD gene mutation depicted in Figure 1A (without the legend). The present "erratum", described below, is also restricted to the genetic and molecular data of the manuscript. Point by point corrections concerning DMD, GRMD and its molecular analysis: 


\begin{abstract}
- Duchenne muscular dystrophy (DMD) is a human disease characterized by progressive and irreversible skeletal muscle degeneration caused by mutations in the dystrophin gene, which codifies the protein dystrophin (Francke et al., 1985; Kunkel et al., 1985; Ray et al., 1985; Hoffman et al., 1987), instead of "mutations in genes coding for important muscle proteins";

- Dogs had their disease status confirmed by genotyping, which means polymerase chain reaction (PCR) analysis followed by restriction fragment length polymorphism (RFLP), as described by Sharp et al. (1992) and Honeyman et al. (1999);

- DMD patients DO NOT show significant inter- and intrafamiliar clinical variability comparable to the GRMD dog model. In DMD, the progression of the disease is always severe and predictable, and differently from the GRMD dogs there is no neonatal death in humans. In opposition, in Becker muscular dystrophy (BMD), allelic to DMD, we and others observe a wide variability (intra- and inter-familial) in the severity of the phenotype (Vainzof et al., 1993).
\end{abstract}

\title{
INTRODUCTION
}

- DMD patients do not become wheelchair-bound AT 12 years old (exclusively), but UNTIL 12 years old (Zatz, 2004);

- Differently from what the paper states, there are more than two animal models for DMD. In addition to the $m d x$ mouse model (Bulfield et al., 1984; Willmann et al. 2009) and GRMD dogs (Cooper et al., 1988), we can also mention three other canine models, including a rottweiler (Winand et al., 1994), a German short-haired pointer (Schatzberg et al., 1999) and beagle dogs that were mated with GRMD dogs to obtain a breed of a smaller size (Shimatsu et al., 2003). In addition, a feline model also exists, although it does not resemble DMD as closely as the GRMD dog (Kohn et al., 1993). In vertebrates, a DMD zebrafish model was also identified (Bassett et al., 2003);

- All reported GRMD dogs carry a frameshift point mutation in the splice acceptor site in intron 6 of the ortholog X-linked dystrophin gene, leading to the complete absence of the protein in the muscles, with exception of some rare "revertant" fibers that express dystrophin (Sharp et al., 1992). In humans, Duchenne muscular dystrophy can be caused by many different mutations along the gene. By far, the most frequent type are deletions (60-65\%) and duplications, which may occur in $5-10 \%$ of the cases. The remaining mutations are point mutations, splicing errors or small duplication/deletion changes that generate premature stop codons (Koenig et al., 1989; Hu et al., 1990).

\section{MATERIAL AND METHODS}

- Our group established in 2002 one of the two GRMD kennels in Latin America. In both kennels, all dogs are descendant of Beth, a GRMD female carrier donated by Dr. Joe Kornegay (University of North Carolina, USA). Our kennel is located in São Paulo city and the other one is located in Ribeirão Preto;

- All 15 GRMD dogs had their affected status confirmed by genotyping (PCR and RFLP), as aforementioned;

- To clarify, we propose the following legend for Figure 1A: GRMD puppies were 
genotyped within $48 \mathrm{~h}$ after birth. Genomic DNA from blood was used for PCR amplification followed by digestion with Sau96I endonuclease, which generates the 310-bp wild-type band and/or the 150-bp mutant band, as indicated with arrows. Square = male; circle = female; open symbol $=$ unaffected; solid symbol $=$ affected; circle with dot $=$ carrier female .

\section{RESULTS}

- Recently, we described an exceptional GRMD dog, named Ringo, with complete absence of dystrophin expression associated with a mild course of the disease (Ambrósio et al., 2008). Interestingly, one of his descendants, Suflair, is also showing a mild course, although less than his father. We share the same opinion regarding that both dogs, Ringo and Suflair, are unique in our kennel when comparing with other GRMD-affected dogs. However, in the results section it was described that five dogs were included in grade I, including Suflair. In our opinion this is not a correct observation.

\section{DISCUSSION}

- In the cited review from Vainzof and Zatz (2003), there are wrong interpretations. DMD patients DO NOT show important inter- and intrafamiliar clinical variability, as mentioned above. In this review, Vainzof and Zatz (2003) commented about clinical inter- and intrafamilial variability in several other genetic disorders, including SOME other forms of muscular dystrophies, and highlighted the role of possible modifying genes and protein interactions in determining this phenotypic variability;

- We strongly disagree with the following sentence: "Future studies should be carried out to establish if a difference in the levels of dystrophin can also be observed in these dogs and whether these levels may explain the different phenotypes described here". All GRMD dogs analyzed to date in our kennel have a complete dystrophin deficiency, with exception of the rare "revertant" fibers. Indeed, Ringo is an exceptional dog because he is showing a mild course despite the absence of muscle dystrophin;

- The article suggests that both DMD and BMD "are found in patients carrying similar mutations". Some rare cases have been described but they are an exception. According to Monaco et al. (1988), the analysis of deletions in the dystrophin gene shows that patients with Becker dystrophy have "in-frame" deletions whereas patients with Duchenne dystrophy carry "out-of-frame" deletions;

- We strongly disagree with the affirmation that "the milder phenotype in GRMDaffected dogs is due to a modifier gene inherited through male-to-male transmission". This sentence should be excluded from the discussion;

- GRMD females in the kennel DO show clinical variability, and therefore the variation is not restricted to males. On the other hand, the number of affected females, which were followed to date in our kennel, is too small to assess how variable is the phenotype among GRMD female dogs.

\section{ACKNOWLEDGMENTS}

We would like to thank Natássia Vieira and all our colleagues in the Human Genome 
Research Center, Institute of Biosciences, University of São Paulo, São Paulo, SP, Brazil, for the support and helpful suggestions.

\section{REFERENCES}

Ambrósio CE, Valadares MC, Zucconi E, Cabral R, et al. (2008). Ringo, a Golden Retriever Muscular Dystrophy (GRMD) dog with absent dystrophin but normal strength. Neuromuscul. Disord. 18: 892-893.

Bassett DI, Bryson-Richardson RJ, Daggett DF, Gautier P, et al. (2003). Dystrophin is required for the formation of stable muscle attachments in the zebrafish embryo. Development 130: 5851-5860.

Bulfield G, Siller WG, Wight PA and Moore KJ (1984). X chromosome-linked muscular dystrophy (mdx) in the mouse. Proc. Natl. Acad. Sci. U. S. A. 81: 1189-1192.

Cooper BJ, Winand NJ, Stedman H, Valentine BA, et al. (1988). The homologue of the Duchenne locus is defective in X-linked muscular dystrophy of dogs. Nature 334: 154-156.

Francke U, Ochs HD, de Martinville B, Giacalone J, et al. (1985). Minor Xp21 chromosome deletion in a male associated with expression of Duchenne Muscular Dystrophy, chronic granulomatous disease, retinitis pigmentosa, and McLeod syndrome. Am. J. Hum. Genet. 37: 250-267.

Hoffman EP, Brown RH Jr and Kunkel LM (1987). Dystrophin: the protein product of the Duchenne Muscular Dystrophy locus. Cell 51: 919-928.

Honeyman K, Carville KS, Howell JM, Fletcher S, et al. (1999). Development of a snapback method of single-strand conformation polymorphism analysis for genotyping Golden Retrievers for the X-linked muscular dystrophy allele. Am. J. Vet. Res. 60: 734-737.

Hu XY, Ray PN, Murphy EG, Thompson MW, et al. (1990). Duplicational mutation at the Duchenne Muscular Dystrophy locus: its frequency, distribution, origin, and phenotypegenotype correlation. Am. J. Hum. Genet. 46: 682-695.

Koenig M, Beggs AH, Moyer M, Scherpf S, et al. (1989). The molecular basis for Duchenne versus Becker Muscular Dystrophy: correlation of severity with type of deletion. Am. J. Hum. Genet. 45: 498-506.

Kohn B, Guscetti F, Waxenberger M and Augsburger H (1993). Muscular dystrophy in a cat. Tierarztl. Prax. 21: 451-457.

Kunkel LM, Monaco AP, Middlesworth W, Ochs HD, et al. (1985). Specific cloning of DNA fragments absent from the DNA of a male patient with an X chromosome deletion. Proc. Natl. Acad. Sci. U. S. A. 82: 4778-4782.

Monaco AP, Bertelson CJ, Liechti-Gallati S, Moser H, et al. (1988). An explanation for the phenotypic differences between patients bearing partial deletions of the DMD locus. Genomics 2: 90-95.

Ray PN, Belfall B, Duff C, Logan C, et al. (1985). Cloning of the breakpoint of an X;21 translocation associated with Duchenne Muscular Dystrophy. Nature 318: 672-675.

Schatzberg SJ, Olby NJ, Breen M, Anderson LV, et al. (1999). Molecular analysis of a spontaneous dystrophin 'knockout' dog. Neuromuscul. Disord. 9: 289-295.

Sharp NJ, Kornegay JN, Van Camp SD, Herbstreith MH, et al. (1992). An error in dystrophin mRNA processing in golden retriever muscular dystrophy, an animal homologue of Duchenne Muscular Dystrophy. Genomics 13: 115-121.

Shimatsu Y, Katagiri K, Furuta T, Nakura M, et al. (2003). Canine X-linked muscular dystrophy in Japan (CXMDJ). Exp. Anim. 52: 93-97.

Vainzof M and Zatz M (2003). Protein defects in neuromuscular diseases. Braz. J. Med. Biol. Res. 36: 543-555.

Vainzof M, Passos-Bueno MR, Takata RI, Pavanello RC, et al. (1993). Intrafamilial variability in dystrophin abundance correlated with difference in the severity of the phenotype. J. Neurol. Sci. 119: 38-42.

Willmann R, Possekel S, Dubach-Powell J, Meier T, et al. (2009). Mammalian animal models for Duchenne muscular dystrophy. Neuromuscul. Disord. 19: 241-249.

Winand N, Pradham D and Cooper B (1994). Molecular Characterization of Severe Duchenne-type Muscular Dystrophy in a Family of Rottweiler Dogs. In: Proceedings of the Molecular Mechanisms of Neuromuscular Disease. Muscular Dystrophy Association, Tucson.

Zatz M (2004). Genômica das Doenças Neuromusculares e Neurodegenerativas. In: Genômica (Mir L, ed.). Atheneu, São Paulo, 345-360. 